\title{
Optic neuropathy caused by expanded Onodi cell mucocele
}

\author{
Tsunetaro Morino, ${ }^{1,2}$ Taichi Yanagihara, ${ }^{1}$ Hiroki Kuroyanagi, ${ }^{1}$ Hiroto Ohto ${ }^{1}$
}

'Department of

Otorhinolaryngology, Asahi General Hospital, Asahi, Chiba, Japan

${ }^{2}$ Department of Otorhinolaryngology, Jikei University School of Medicine, Minato-ku, Japan

Correspondence to Dr Tsunetaro Morino; moritune@jikei.ac.jp

TM and TY contributed equally.

Accepted 1 May 2020

Check for updates

(c) BMJ Publishing Group

Limited 2020. No commercial re-use. See rights and permissions. Published by BMJ.

\begin{tabular}{l}
\hline To cite: Morino T, \\
Yanagihara T, Kuroyanagi H, \\
et al. BMJ Case Rep \\
2020;13:e235311. \\
doi:10.1136/bcr-2020- \\
235311 \\
\hline
\end{tabular}

\section{DESCRIPTION}

A 71-year-old man presented to the ophthalmology clinic with 10 days of gradual visual loss and blurred left eye vision. He was treated for chronic sinusitis 51 years previously. He underwent both Caldwell-Luc and Killian's surgeries. His medical history included diabetes mellitus and hypertension. A visual acuity test showed 20/50 in his left eye and 20/25 in his right eye. A visual field test revealed the expansion of the Mariotte blind spot, while ocular motility and main cranial nerve function were undisturbed. Funduscopic examination was unremarkable. CT revealed a soft tissue density lesion in the left posterior ethmoidal air cell (i.e., Onodi cell) and a bony defect of the optic canal (figure 1A-C). T1 and T2 MRIs demonstrated a low-intensity lesion in the Onodi cell, and enhanced MRI revealed no contrast effect, even in the surrounding tissue (figure 1D-F). His sudden visual loss was caused by an expanded Onodi cell mucocele. The surrounding tissue, including the optic nerve, exhibited no inflammation. He underwent surgical removal of the lesion by endoscopic sinus surgery 11 days after the onset of symptoms. The left ethmoid sinus was opened, and the left superior nasal concha was removed. The left sphenoid sinus was widely opened from the natural ostium (figure 2A) and the Onodi cell on top of the sphenoid sinus was punctured and the cyst contents were removed (figure $2 \mathrm{~B}$ ). The sinus was opened widely so as not to damage the optic nerve (figure $2 \mathrm{C}, \mathrm{D}$ ). One day after the surgical drainage he experienced dramatic visual recovery.

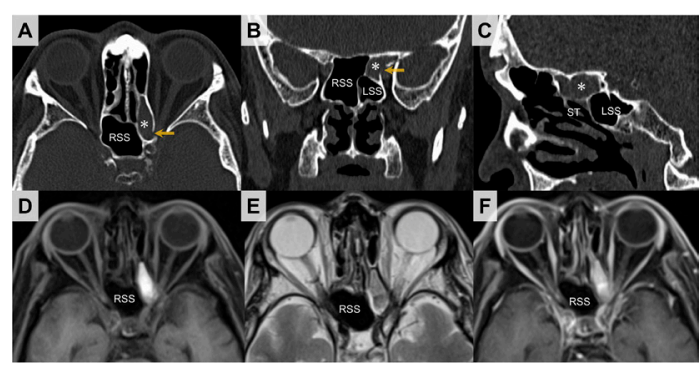

Figure 1 Axial (A), coronal (B) and sagittal (C) CT findings before the operation. An Onodi cell (white asterisk) was observed on top of the left sphenoid sinus, and a bone defect (yellow arrow) of the optic canal was observed in the Onodi cell. T1-weighted (D), T2-weighted (E) and enhanced T1-weighted (F) MRI findings before the operation. The lesion demonstrated high intensity on all images, and enhanced MRI revealed no contrast effect, including the surrounding tissue. T1-weighted MRI was treated with fat suppression. LSS, left sphenoid sinus; RSS, right sphenoid sinus; ST: superior turbinate.

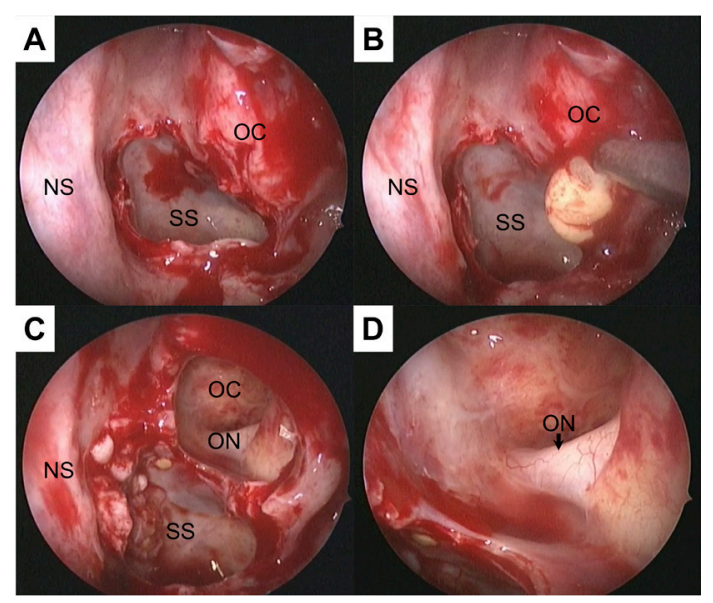

Figure 2 Operative finding by endoscopic sinus surgery. (A) Left sphenoid sinus was widely opened from the natural ostium after removing the left superior nasal concha. (B) The Onodi cell on top of the sphenoid sinus was punctured to remove the cyst contents. (C) The Onodi cell was widely opened so as not to damage the optic nerve. (D) A bone defect of the optic canal was observed. NS, nasal septum; OC, Onodi cell; ON, optic nerve; SS, sphenoid sinus.

Postoperative findings after 3 months confirmed the removal of the Onodi cell mucocele (online supplementary file 1 ).

The Onodi cell is the most posterior ethmoidal cell that pneumatises laterally and superiorly to the sphenoid sinus. ${ }^{1}$ The optic nerve runs close to the small cavity of the Onodi cell. A mucocele is a cystic lesion limited by the mucosa of the paranasal sinus and occurs secondary to sinus drainage obstruction, resulting in the retention of sinus secretions. Optic neuropathy attributable to the Onodi cell mucocele occurs secondary to a mass on the optic nerve, ischaemia from compression of the vasa nervorum and inflammation. In our case, the Onodi cell mucocele resulted from previous sinus surgery. A decompression of the mass on the optic nerve improved visual acuity.

Opening an Onodi cell is difficult due to the relationship between the Onodi cell and sphenoid sinus. Wada reported the sphenoid sinus can be opened safely following preoperative assessment of the anterior wall, the position of the superior turbinate, and ostium of the sphenoid sinus. ${ }^{2}$ Widely opening the sphenoid sinus from the ostium and removing the superior nasal concha confirmed the location of the Onodi cell and opened it without damaging the optic nerve. 
Primary treatment for Onodi cell-associated optic neuropathy is urgent surgical decompression. Endoscopic sinus surgery is frequently used due to its lower complication rate, less invasive nature and earlier patient recovery. ${ }^{3}$ Onodi cell mucoceles should be considered in the differential diagnosis of unilateral visual loss.

\section{Learning points}

Onodi cell mucoceles should be considered in the differential diagnosis of unilateral visual loss.

- CT and MRI were used to effectively diagnose the Onodi cell mucocele and determine the location of the sphenoid sinus and optic nerve.

- Urgent surgical decompression of the Onodi cell mucocele led to improved visual acuity.
Contributors TM, TY, HK and HO examined the patient and diagnosed them. TY treated the patient. TM wrote the manuscript. All authors discussed the results and contributed to the final approval of the manuscript.

Funding The authors have not declared a specific grant for this research from any funding agency in the public, commercial or not-for-profit sectors.

Competing interests None declared.

Patient consent for publication Obtained.

Provenance and peer review Not commissioned; externally peer reviewed.

\section{REFERENCES}

1 Onodi A. Das Verhaltnis des Nervus opticus zu Der KeilbeinhOhle und insbesondere zu Der hintersten Siebbeinzelle. Arch Laryng 1903;14:360-74.

2 Wada K, Moriyama H, Edamatsu H, et al. Identification of Onodi cell and new classification of sphenoid sinus for endoscopic sinus surgery. Int Forum Allergy Rhinol 2015:5:1068-76

3 Tzamalis A, Diafas A, Riga P, et al. Onodi cell mucocele-associated optic neuropathy: a rare case report and review of the literature. J Curr Ophthalmol 2019;14.

Copyright 2020 BMJ Publishing Group. All rights reserved. For permission to reuse any of this content visit

https://www.bmj.com/company/products-services/rights-and-licensing/permissions/

BMJ Case Report Fellows may re-use this article for personal use and teaching without any further permission.

Become a Fellow of BMJ Case Reports today and you can:

- Submit as many cases as you like

- Enjoy fast sympathetic peer review and rapid publication of accepted articles

Access all the published articles

Re-use any of the published material for personal use and teaching without further permission

Customer Service

If you have any further queries about your subscription, please contact our customer services team on +44 (0) 2071111105 or via email at support@bmj.com.

Visit casereports.bmj.com for more articles like this and to become a Fellow 